\title{
DESAIN SISTEM LAYANAN PUBLIK KECAMATAN DENGAN METODE LOCATION BASED SERVICE BERBASIS ANDROID
}

\author{
Laurentinus \\ Fakultas Ilmu Komputer, Program Studi Teknik Informatika \\ STMIK Atma Luhur \\ Email: laurentinus@atmaluhur.ac.id
}

\begin{abstract}
ABSTRAK
Dalam melakukan pelayanan publik kepada masyarakat, instansi pemerintah diharapkan dapat memberikan kemudahan dalam mengayomi dan garis depan penyelenggaraan pemerintahan dalam melayani masyarakat berada di tingkat kecamatan. Kecamatan memiliki posisi yang strategis, sehingga apapun yang menjadi kinerja kecamatan merupakan kinerja Kabupaten. Tata kelola sistem pemerintahan serta pelayanan kecamatan yang baik akan berdampak terhadap birokrasi yang bersih, profesional, dan berwibawa. Pada sisi lain tata kelola pemerintahan serta pelayanan kecamatan yang baik akan memberikan efek positif terhadap tumbuhnya partisipasi masyarakat dalam pembangunan, meningkatnya kepercayaan masyarakat terhadap pemerintah, tegaknya supremasi hukum, transparansi dalam penyelenggaraan kelola pemerintahan, efektif dan efisien. Namun sayangnya, kecamatan di Bangka Selatan khususnya air gegas masih menggunakan cara manual dalam melayani masyarakat dimana masyarakat harus datang terlebih dahulu dan mengisi formulir surat permohonan sehingga kurang efektif dan efisien. Penelitian ini bertujuan membuat sistem yang dapat membantu dan meningkatkan pelayanan kepada masyarakat khususnya dalam pelayanan surat permohonan. Sehingga masalah yang dialami seperti susahnya masyarakat dalam membuat surat dapat terhindari melalui sistem ini, penerapan metode Location Based Service mempermudah masyarakat sehingga tidak perlu datang ke kecamatan dan kelurahan. Hasil pengujian terhadap User Acceptance testing yaitu 85.6\%, sehingga dapat disimpulkan bahwa sistem layanan publik menggunakan metode location base service berjalan dengan akurat dan dapat memberikan kinerja yang sesuai terkait performance, social influence, effort expectancy, supporting facilitating, use behavior dan behavioral intention.
\end{abstract}

Kata kunci: pelayanan publik; Kecamatan; LBS; android.

\section{ABSTRACT}

In providing services to the community, Government agencies are expected to provide facilities to protect and the front lines of government administration in serving the community at the sub-district level. The sub-district has a strategic position so that each district becomes a district that has a performance. Governance of the government system with sub-district services that will improve a clean, professional, and authoritative bureaucracy. On the other hand, governing governance with a good sub-district will have a positive effect on the growth of the community in development, trusting the community with the government, raising it with the rule of law, supporting the administration of government, effective and efficient. However, the sub-district in South Bangka, especially the spring water, still uses manual methods to serve the community where the community must come first and fill out a letter requesting a form to be ineffective and inefficient. This research makes a system that can help and improve services to the community, specifically in the service letter application. How to overcome the problems faced by the community in making the letter can be avoided through this system, the application of the Location-Based Services method makes it easier for the community, so they do not need to come to the districts and villages. The results of User Acceptance testing is $85.6 \%$, so it can be concluded the public service system using location-based service methods runs well and can provide appropriate performance related to performance, social influence, effort expectations, supporting facilitation, use behavioral and behavioral intentions.

Keywords: public service; LBS; android.

\section{PENDAHULUAN}

Negara Indonesia berlandasan Pancasila dan UUD Tahun 1945 pada hakikatnya berkewajiban untuk merlindungi dan memberikan pengakuan terhadap penentuan status pribadi serta status hukum untuk 
setiap peristiwa kependudukan dan peristiwa penting yang dilakukan/dialami oleh penduduk yang berada di wilayah maupun diluar wilayah Indonesia. Peristiwa kependudukan yang dialami masyarakat antara lain adalah pindah datang untuk menetap, pindah alamat, menetap terbatas, perubahan status orang/pekerja asing tinggal terbatas menjadi tinggal tetap dan juga peristiwa kelahiran, perkawinan, kematian, perceraian, pengangkatan anak, pengakuan anak, dan pengesahan anak, ganti nama, perubahan status kewarganegaraan, dan peristiwa penting lainnya yang dialami oleh penduduk merupakan peristiwa yang harus dilaporkan kepada pemerintah karena berimplikasi mengalami perubahan data identitas penduduk atau surat keterangan kependudukan.

Namun sayangnya semua pelaporan ini masih mewajibkan masyarakat mendatangi kantor kecamatan dan kelurahan, dengan pengarsipan \& pencatatan dokumen secara manual. Cara konvensional ini mengakibatkan ketidakefisien dalam pelayanan masyarakat.

Pelayanan pembuatan surat permohonan pada Kantor Camat Desa Air Gegas masih menggunakan cara manual, dimana pegawai kecamatan membuat surat permohonan secara manual dan masyarakat harus terlebih dahulu datang untuk melakukan pengajuan surat permohonan. Hal ini menjadi tidak efektif dan efisien, dilihat dari jumlah frekuensi surat yang diproses kecamatan setiap harinya dan surat yang beragam jenis. [1][2]

Berdasarkan masalah ini maka dibutuhkannya sistem pelayanan publik yang dapat diakses dimana saja menggunakan mobile phone berbasis android, dengan metode Location base service maka dokumen dapat diantar ke lokasi rumah masyarakat sehingga efektif dan efisiensi waktu masyarakat.

Anders fredriksson melakukan penelitian dengan judul "Location-allocation of public services Citizen access, transparency and measurement. A method and evidence from Brazil and Sweden", penelitian ini mengilustrasikan dengan menganalisis Pusat Layanan Warga di Brasil dan Swedia. pertama-tama menunjukkan bagaimana alokasi spasial yang optimal dari pusat-pusat tersebut dapat diperoleh dengan data yang sebagian besar tersedia untuk umum, yang memungkinkan transparansi data. Berdasarkan yang optimalisasi, kami kemudian memperkenalkan metrik misalokasi layanan publik yang berbeda. Penelitian ini menunjukkan bagaimana metrik misalokasi tersebut dapat dikaitkan dengan hasil sosial ekonomi dan variabel politik dan lainnya, sehingga menyarankan metode yang dapat menjadi alat yang berguna dalam analisis kinerja sektor publik [3]. Siddhartha S.Syam telah melakukan peneltian "A comprehensive location-allocation method for specialized healthcare services", Makalah ini berfokus pada pengembangan, solusi, dan penerapan model alokasi lokasi untuk layanan perawatan kesehatan khusus seperti perawatan dan rehabilitasi yang diperlukan untuk stroke atau cedera otak traumatis. Model ini didasarkan pada pengalaman kami dengan jaringan layanan terpadu Departemen Urusan Veteran. Penerapan model ini diuji oleh eksperimen manajerial yang luas menggunakan data yang berasal dari salah satu layanan kesehatan khusus Departemen Urusan Veteran. Penelitian ini menyelidiki efek dari lima faktor penting: (1) tingkat sentralisasi layanan, (2) tingkat layanan diamanatkan oleh ketajaman, (3) kehilangan biaya masuk karena ketajaman, (4) fasilitas biaya penalti yang berlebihan karena ketajaman dan (5) target tingkat pemanfaatan oleh unit ketajaman dan perawatan. Kami memeriksa kekuatan serangan balik yang hadir dalam membuat keputusan lokasi layanan kesehatan dan imbal balik yang dihasilkan dari sifat multi-tujuan yang tersirat dari sistem. Eksperimen dan analisis menunjukkan bahwa faktor utama percobaan memiliki pengaruh yang signifikan terhadap penugasan yang optimal dari kabupaten penerimaan ke unit perawatan [4]. Jefri Alfa Razaq telah melakukan penelitian "Sistem Informasi Publik Layanan Kesehatan menggunakan Metode Location Based Service di Kota Semarang" Penelitian ini bertujuan untuk merancang sistem informasi berbagai lokasi untuk masyarakat yang membutuhkan petunjuk jalan menuju lokasi pelayanan kesehatan masyarakat. Berdasarkan data pantauan masih banyak masyarakat yang belum/tidak mengetahui lokasi terdekat dalam mengakses layanan kesehatan di kota Semarang. Manfaatnya dari penelitian ini yaitu memberikan kemudahan, ketepatan, dan kecepatan dalam mengetahui posisi peta lokasi layanan kesehatan terdekat dari pengguna dengan disertai informasi pendukung menuju lokasi seperti visualisasi objek dalam bentuk maps melalui perangkat mobile Android dan rute untuk menuju lokasi layanan kesehatan yang dipilih, pencarian lokasi, dan menu pendukung pengguna lainnya [5].

\section{METODOLOGI PENELITIAN}

Pengembangan Aplikasi Pelayanan Publik Kecamatan menggunakan model prototipe agar semua proses pengembangan sistem dapat terstruktur dan dilaksanakan dengan baik. 


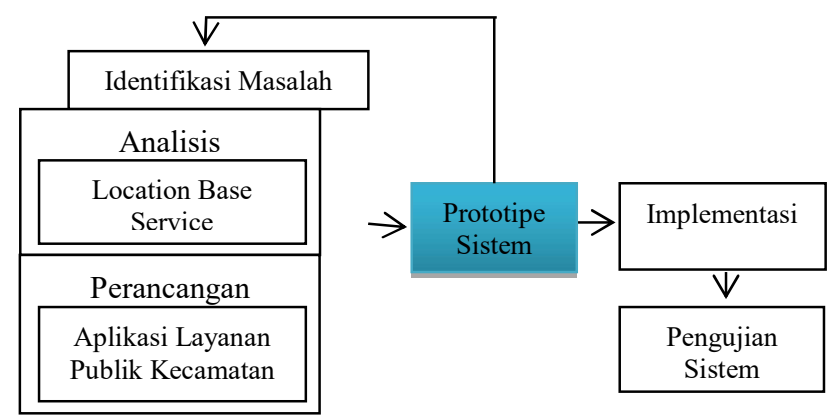

Gambar 1. Model Pengembangan Perangkat Lunak

Berikut ini penjelasan dari beberapa tahapan dari model pengembangan :

a. Analisis

Proses Analisis dilakukan secara intensif untuk menspesifikasikan Location Based Service agar dapat diterapkan dan sesuai kebutuhan user.

b. Perancangan

Perancangan sistem adalah proses multi tujuan yang berfokus kepada desain pembuatan sistem pelayanan Publik pada kantor Kecamatan termasuk struktur data, arsitektur sistem, representasi desain interface dan prosedur location based service. hasil dari perancangan ini yaitu prototipe program aplikasi layanan publik kecamatan.

c. Implementasi

Implementasi dilakukan di kantor kecamatan air gegas kabupaten Bangka Selatan.

d. Pengujian

Pengujian berfokus kepada perangkat lunak dari segi proses bisnis dan fungsional User Acceptance.

\section{HASIL DAN PEMBAHASAN}

Tahapan ini menjelaskan mengenai arsitektur dan hasil implementasi dari sistem layanan publik kecamatan menggunakan location based service berbasis android:

\subsection{Arsitektur Sistem}

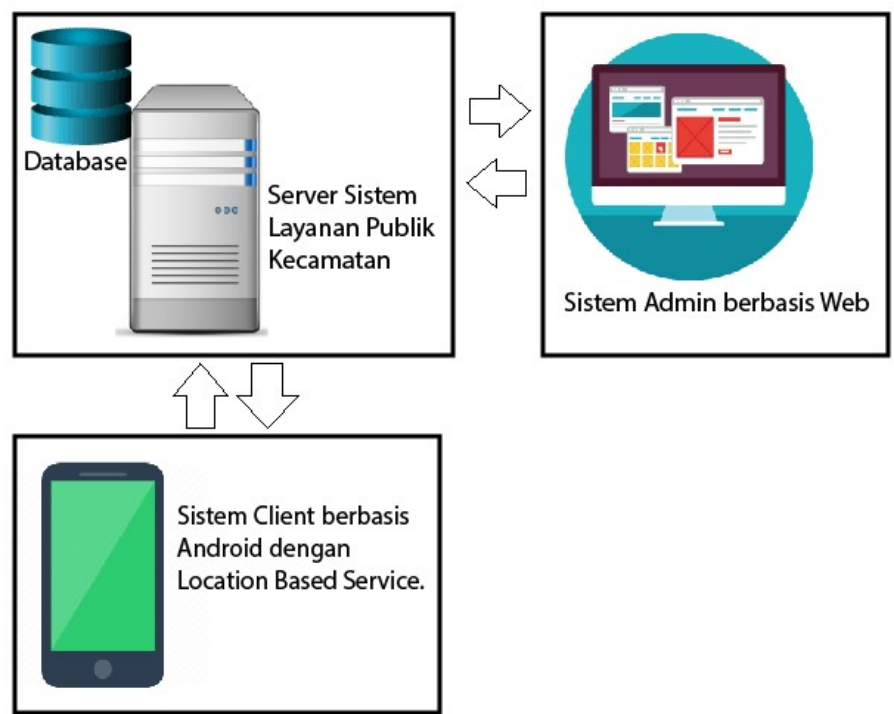

Gambar 2. Desain Arsitektur Sistem 


\subsection{Desain Rancangan Sistem}

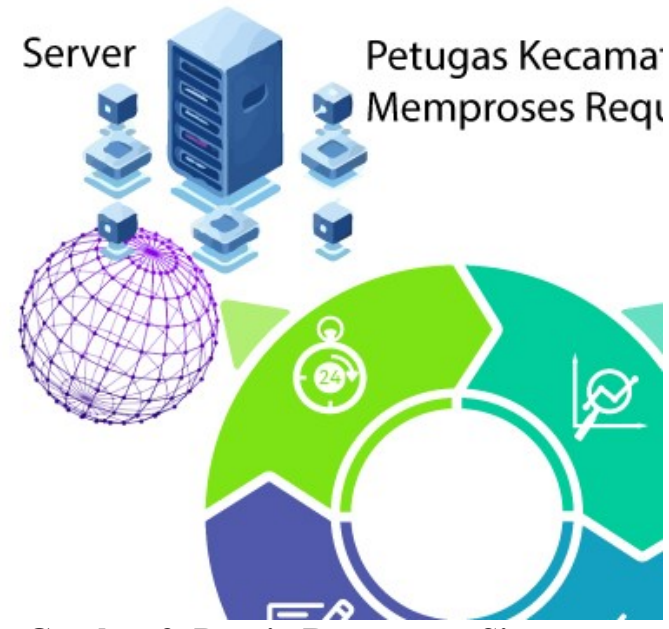

Gambar 3. Desain Rancangan Sistem

Sistem yang dirancang memungkinkan masyarakat meminta layanan surat melalui perangkat mobile, kemudian masuk ke server kecamatan yang akan diproses oleh petugas kecamatan sehingga dokumen yang dibutuhkan selesai. Pengiriman dokumen dilakukan oleh petugas kepada masyarakat berdasarkan lokasi dari LBS yang telah diisi oleh user.

\subsection{Class Diagram}

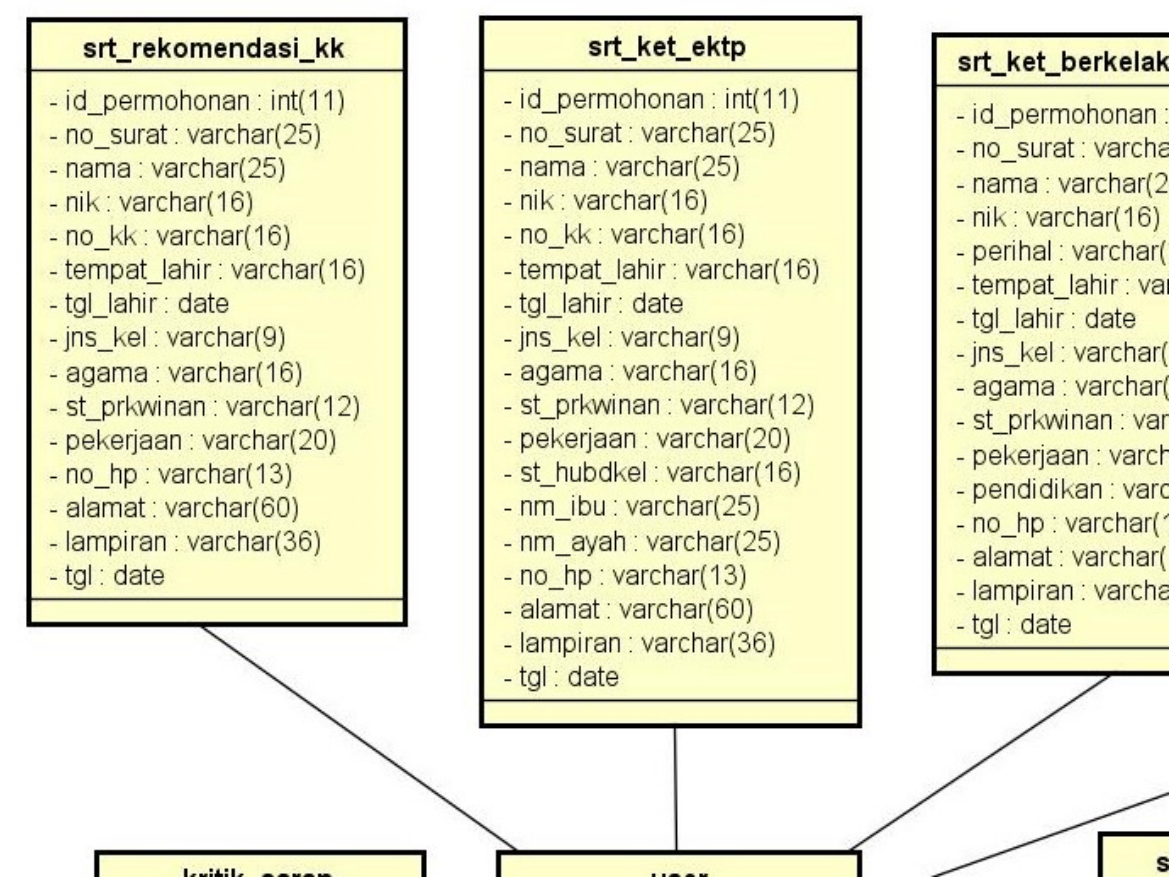

Gambar 4. Class Diagram Sistem Layanan Publik Kecamatan Air Gegas

\subsection{Implementasi Sistem}

Implementasi sistem disini merupakan tahapan setelah prototipe selesai dirancang menjadi kode program. Sistem dirancang sesuai dengan kebutuhan setelah proses evaluasi maka langkah berikutnya yaitu mengimplementasikan aplikasi. Sebelum mengimplementasikan aplikasi layanan publik ini, database aplikasi ini harus terkoneksi ke jaringan publik. Proses pertama yaitu mengakses halaman login. Pengguna diharuskan login dengan mengisi username serta password dengan benar terlebih dahulu sehingga user yang masuk merupakan yang telah terdaftar. 


\subsection{Tampilan Layar Aplikasi User}

a. Tampilan layar menu pendaftaran akun

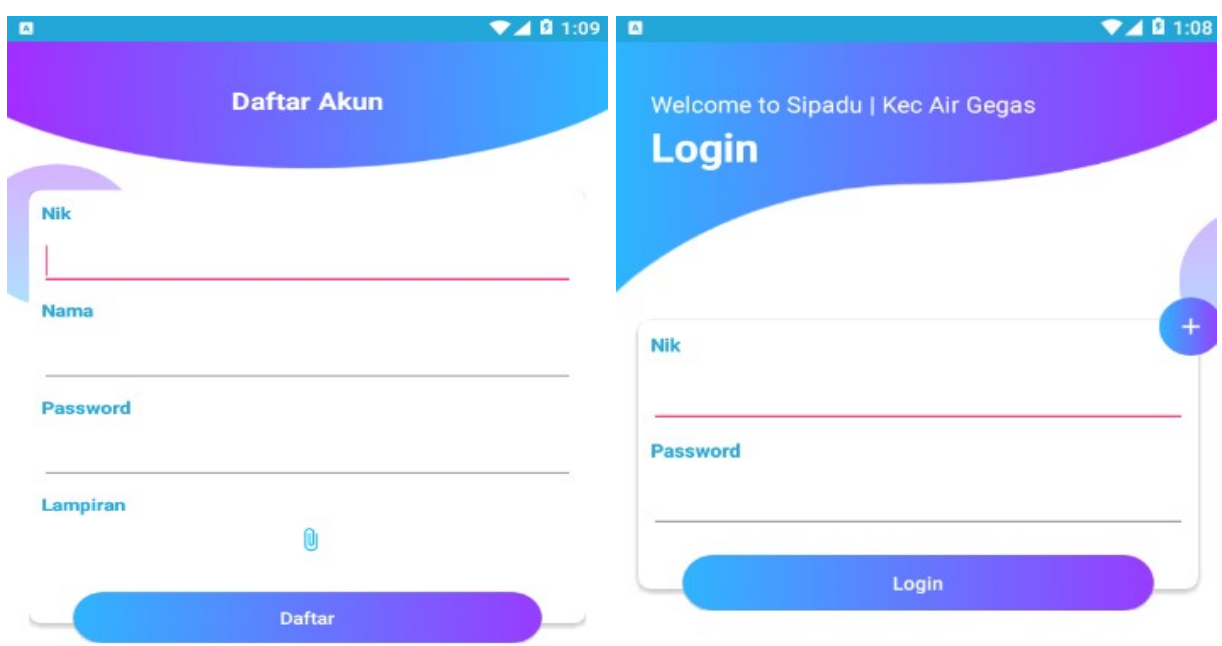

Gambar 5. Tampilan Layar Menu Pendaftaran Akun

Didalam menu pendaftaran akun, user harus mengisi data pendaftaran akun yang benar dan sesuai. Di dalam menu login pengguna harus mengisi email serta password dengan benar.

b. Tampilan halaman menu utama

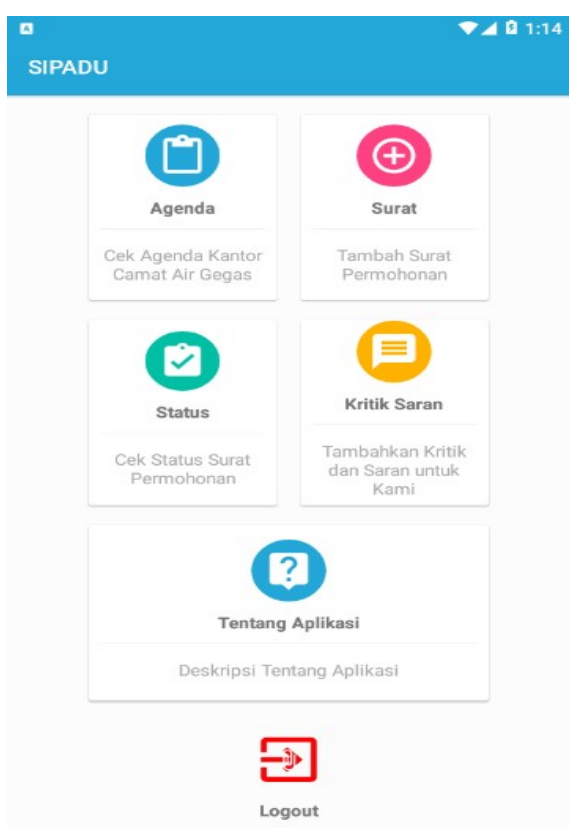

\section{Gambar 6. Tampilan Layar Menu Utama}

Di dalam menu utama terdapat 10 (sepuluh) menu yang akan ditampilkan, terdapat menu pendaftaran akun, login, surat keterangan e-ktp, agenda, surat keterangan berkelakuan baik, surat keterangan dispensasi kelahiran, kritik saran, surat rekomendasi kartu keluarga, status, tentang aplikasi, dan logout. 
c. Tampilan layar menu agenda

Di dalam menu agenda user dapat melihat agenda / kegiatan yang ada di kantor kecamatan.

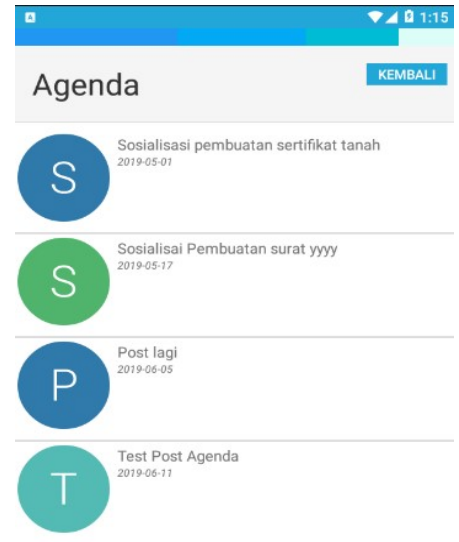

\section{Gambar 7. Tampilan Layar Menu Agenda}

d. Tampilan layar menu surat keterangan e-ktp

Di dalam menu surat keterangan e-ktp, user dapat mengisi data surat keterangan e-ktp dengan benar dan sesuai.

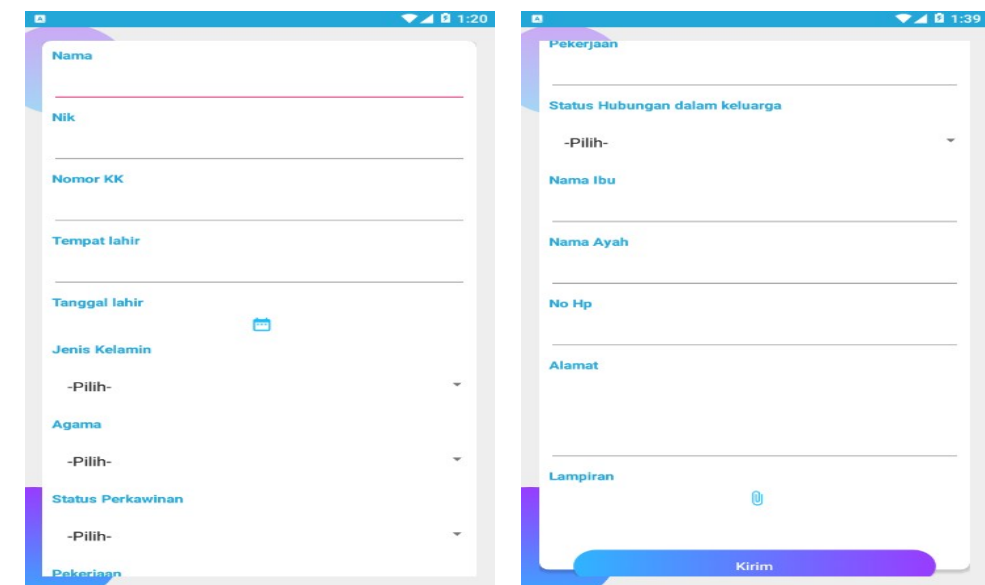

Gambar 8. Tampilan Layar Menu Surat Keterangan E-Ktp

e. Tampilan layar menu surat keterangan dispensasi kelahiran

Di dalam menu surat keterangan e-ktp, user dapat mengisi data surat keterangan e-ktp dengan benar dan sesuai.

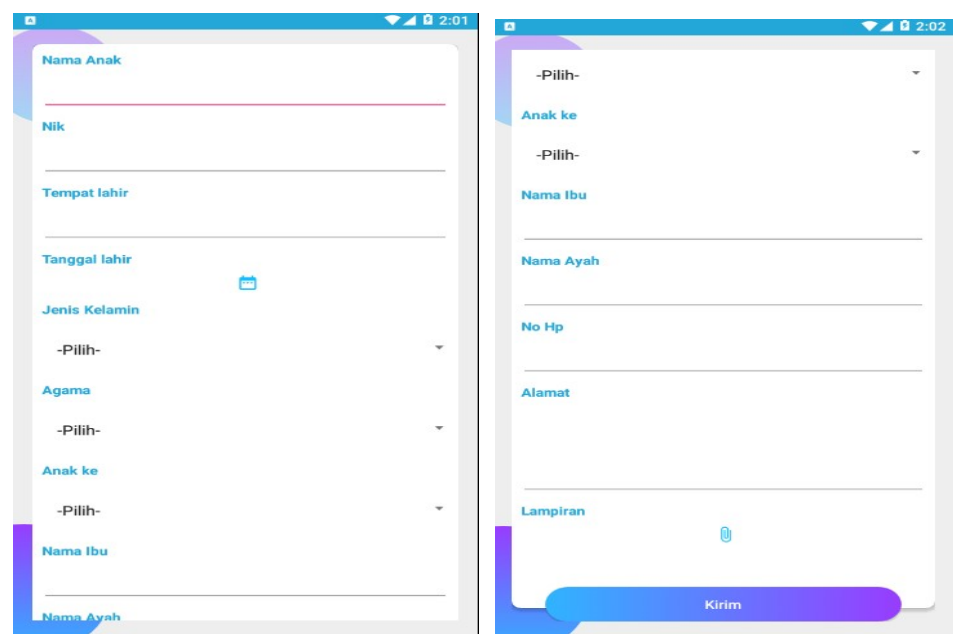

Gambar 9. Tampilan Layar Menu Surat Keterangan Dispensasi Kelahiran 
f. Tampilan layar menu surat keterangan berkelakuan baik

Di dalam menu surat keterangan e-ktp, user dapat mengisi data surat keterangan e-ktp dengan benar dan sesuai.

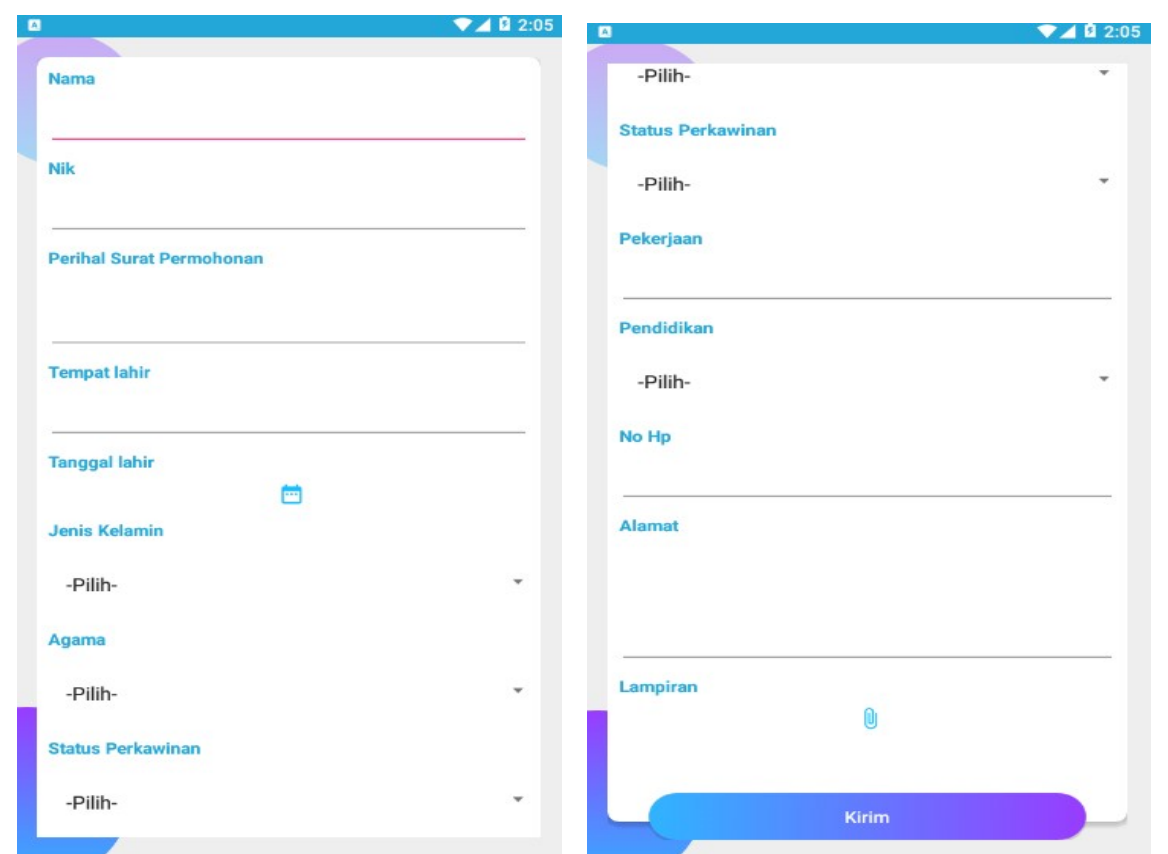

Gambar 10. Tampilan Layar Menu Surat Keterangan Berkelakuan Baik

g. Tampilan layar menu surat rekomendasi kartu keluarga

Di dalam menu surat keterangan e-ktp, user dapat mengisi data surat keterangan e-ktp dengan benar dan sesuai.

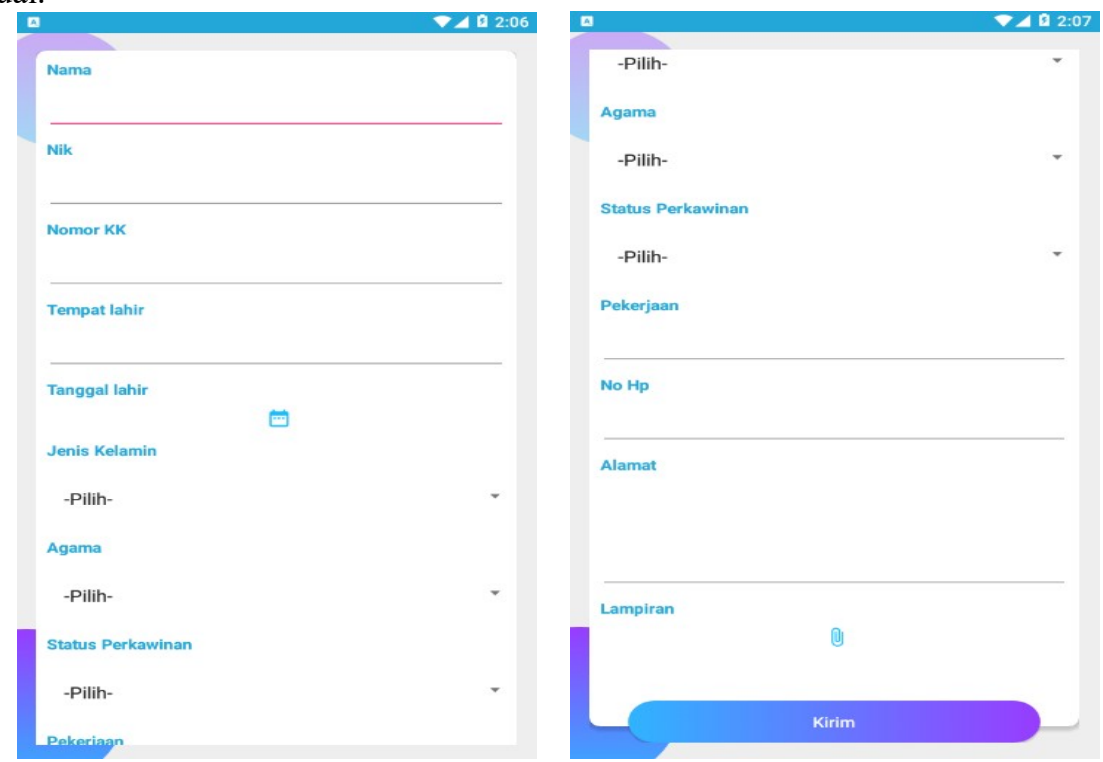

Gambar 11. Tampilan Layar Surat Rekomendasi Kartu Keluarga 
h. Tampilan layar menu status

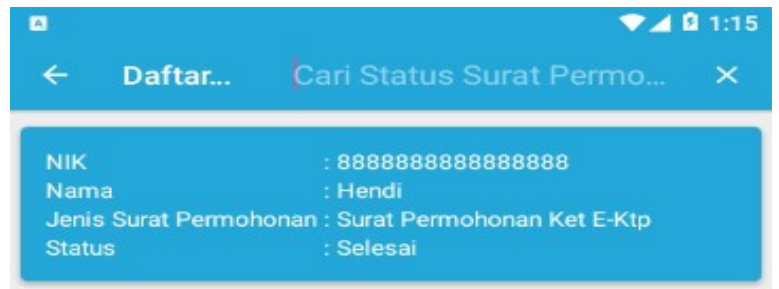

\section{Gambar 12. Tampilan Layar Menu Status}

i. Tampilan Layar Location Base service

Di dalam submit pengajuan surat, user diharuskan mengeset lokasi user sehingga proses pengiriman sesuai dengan lokasi user.

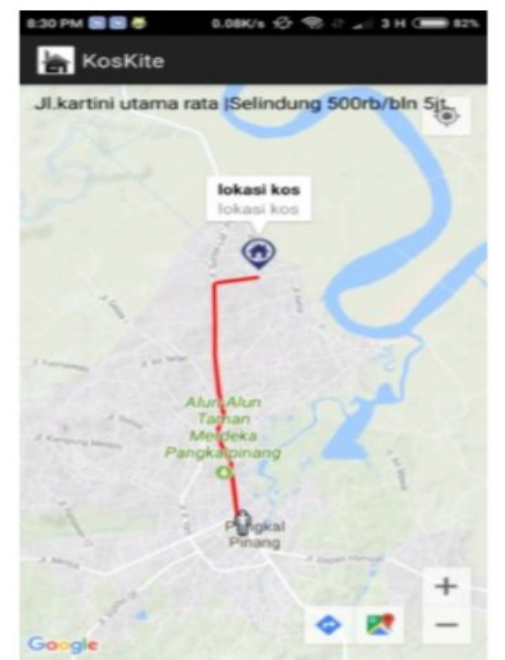

Gambar 13. Tampilan Menu Cek Lokasi User

Tampilan Layar Admin Sistem Kecamatan berbasis web

a. Tampilan halaman login

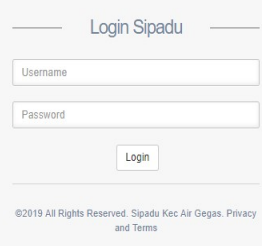

\section{Gambar 14. Tampilan Halaman Login}

Di dalam halaman login, admin kecamatan dapat mengisi email dan password untuk masuk ke halaman dashboard. 
b. Tampilan halaman dashboard

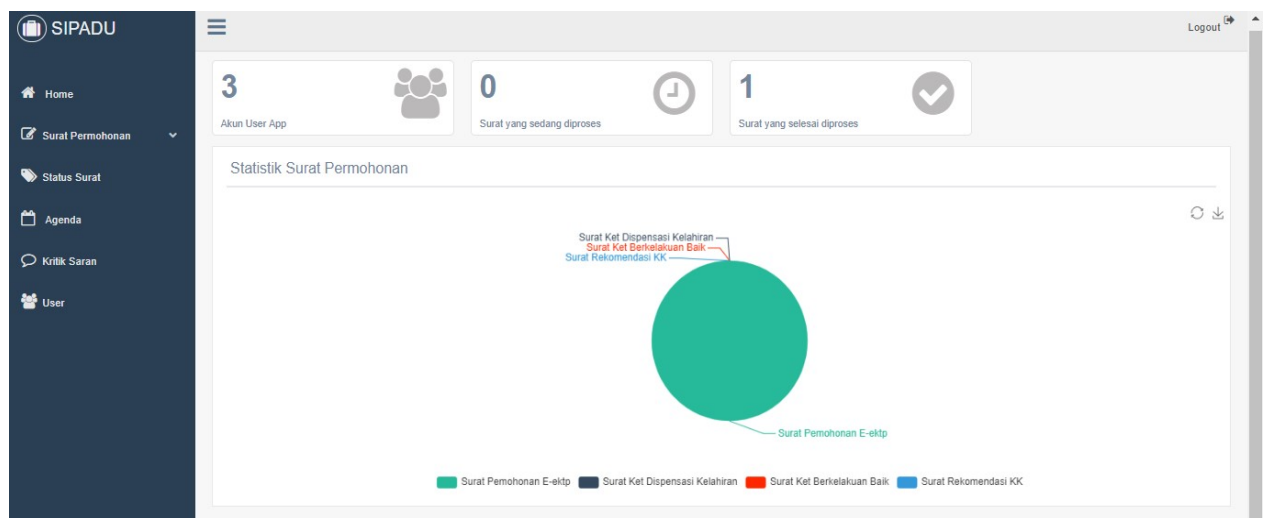

Gambar 15. Tampilan Halaman Dashboard

Di dalam halaman dashboard terdapat menu surat keterangan e-ktp, surat keterangan berkelakuan baik, surat keterangan dispensasi kelahiran, surat rekomendasi kartu keluarga, status surat, agenda, kritik saran dan ,user.

c. Tampilan halaman surat keterangan e-ktp

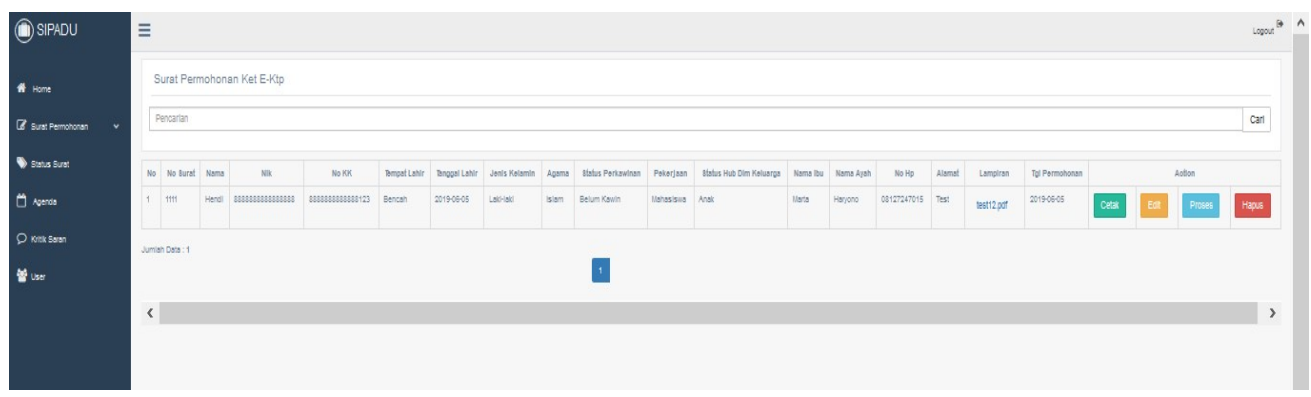

\section{Gambar 16 Tampilan Halaman Surat Keterangan E-Ktp}

Di dalam halaman surat keterangan e-ktp, admin dapat memilih menu cetak, edit, proses, dan hapus data.

d. Tampilan halaman surat keterangan dispensasi kelahiran

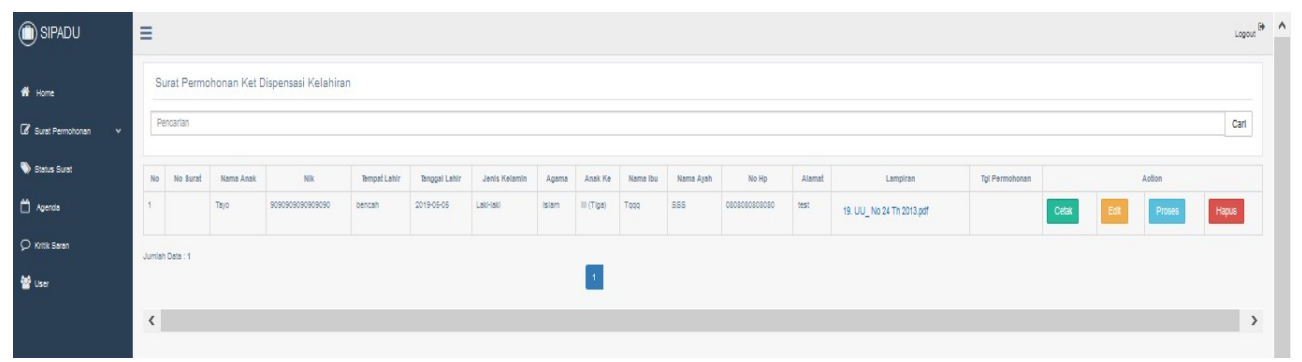

Gambar 17 Tampilan Halaman Surat Keterangan Dispensasi Kelahiran

e. Tampilan halaman surat keterangan berkelakuan baik

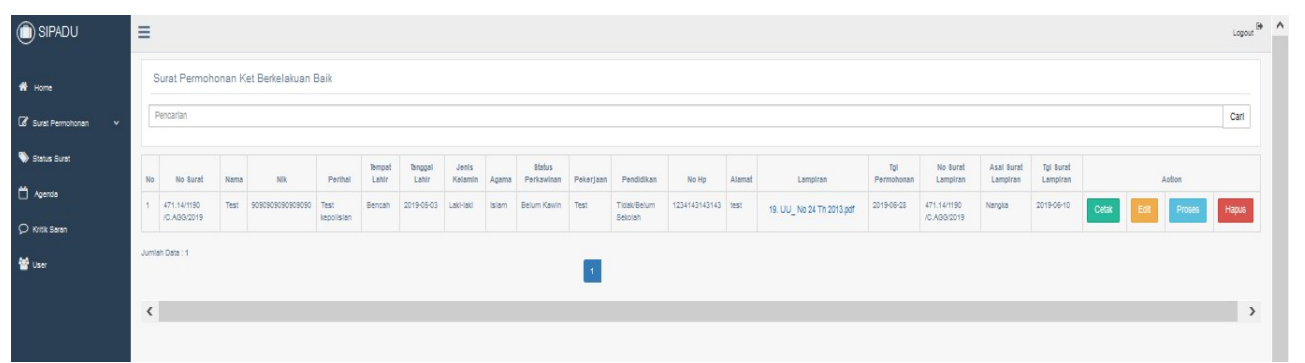

Gambar 18 Tampilan Halaman Surat Keterangan Berkelakuan Baik 
Di dalam halaman surat keterangan berkelakuan baik, admin dapat memilih menu cetak, edit, proses, dan hapus data.

f. Tampilan halaman surat rekomendasi kartu keluarga

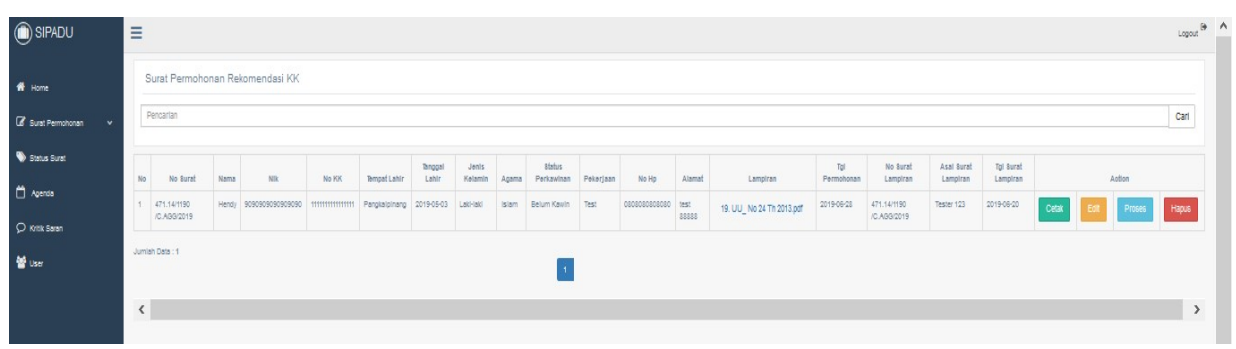

Gambar 19. Tampilan Layar Surat Rekomendasi Kartu Keluarga

g. Tampilan halaman status surat

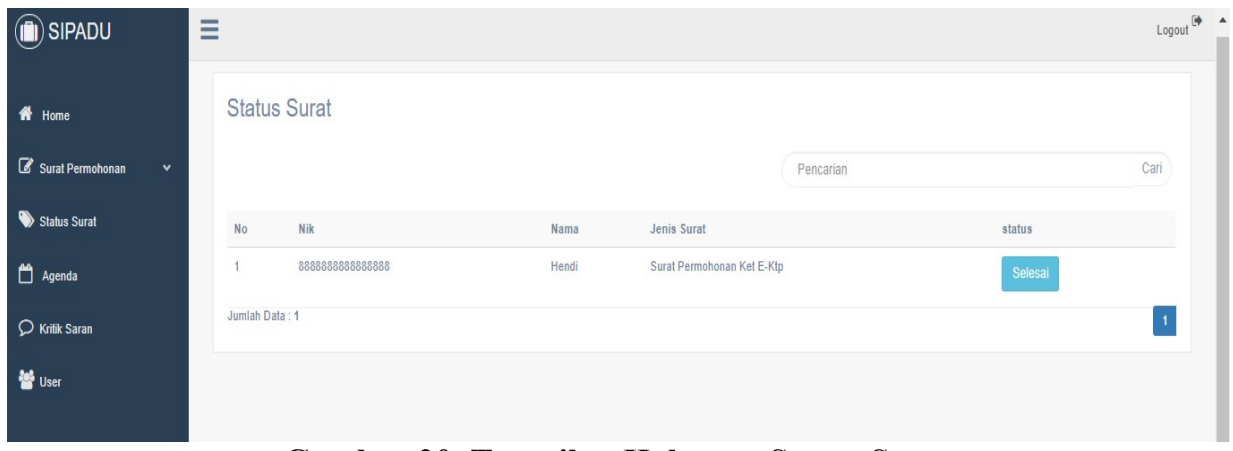

\section{Gambar 20. Tampilan Halaman Status Surat}

h. Tampilan halaman agenda
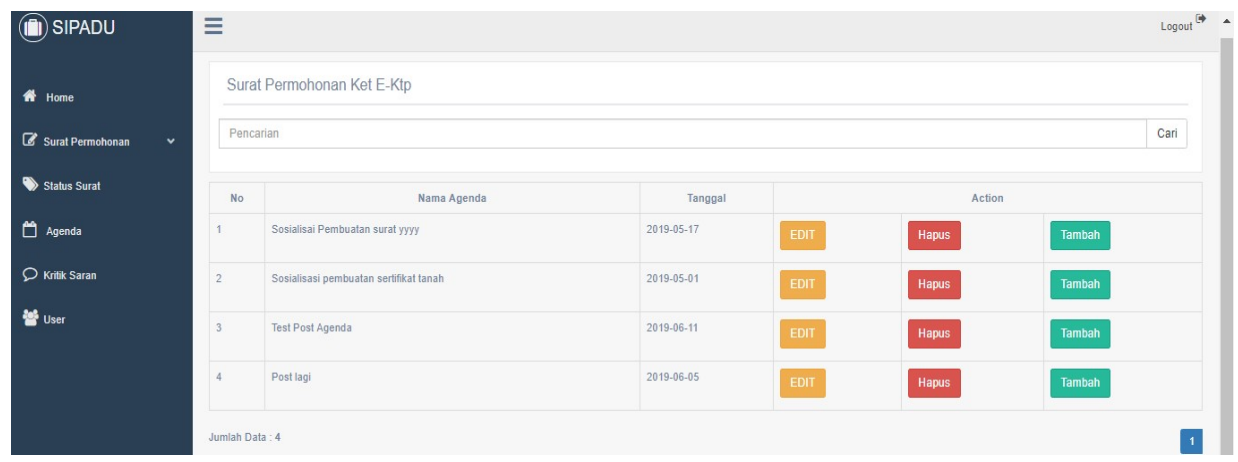

Gambar 21 .Tampilan Agenda

\section{PENGUJIAN}

Pengujian terhadap pengguna diuji menggunakan kuisioner, dalam perhitungan data kuisioner diproses berdasarkan skala likert. Pengujian terhadap aplikasi layanan publik terdiri dari 8 pertanyaan kepada masyarakat dengan 20 responden dimana sistem ini diujicoba di kecamatan Air Gegas.

Tabel 1 Pilihan jawaban serta bobot UAT

\begin{tabular}{clc}
\hline Jawaban & \multicolumn{1}{c}{ Penjelasan } & Bobot \\
\hline A & Sangat : Mudah /Sesuai/ Jelas/Bagus/Sering & 5 \\
B & Mudah /Sesuai/ Jelas/ Bagus/Sering & 4 \\
C & Netral/Biasa & 3 \\
D & Cukup : Sulit/Sesuai/ Jelas/Bagus/ Kadang & 2 \\
E & Sangat : Sulit/TidakSesuai/Tidak Bagus/Jarang & 1 \\
\hline
\end{tabular}

Pertanyaan kuisioner pengujian terhadap user acceptance bisa dilihat pada tabel 2 . 
Tabel 2 Variabel pertanyaan pada kuesioner pengujian

\begin{tabular}{lll}
\hline & \multicolumn{1}{c}{ Pertanyaan } & \multicolumn{1}{c}{ Variabel } \\
\hline P1 Apakah Kinerja dari aplikasi meningkatkan daya produktifitas ? & Performance Expectancy \\
P2 Apakah Aplikasi ini memudahkan pekerjaan? & Performance Expectancy \\
P3 Apakah Aplikasi meningkatkan kualitas pelayanan? & Performance Expectancy \\
P4 Apakah metode location based service telah sesuai? & Performance Expectancy \\
P4 Apakah Aplikasi meningkatkan efisiensi dan efektifitas? & Effort Expectancy \\
P5 Apakah sistem mudah dioperasikan? & Effort Expectancy \\
P6 Apakah Interface sistem yang ditampilkan nyaman? & Effort Expectancy \\
P7 Apakah anda mendukung sistem ini diterapkan? & Social Influence \\
P7 Apakah kemampuan pengoperasian pengguna sudah memadai? & Supporting Facilitating \\
P8 Apakah Sistem Kompatibel dengan perangkat mobile? & Supporting Facilitating \\
P9 Apakah Aplikasi layak memperbaharui metode pelayanan & Behavioral Intention \\
& \\
sebelumnya? & Use Behavior \\
& \\
\hline
\end{tabular}

Hasil pengujian User Acceptance terhadap masyarakat dapat dilihat pada tabel 3.

Tabel 3 Hasil pengujian UAT

\begin{tabular}{|c|c|c|c|c|c|c|c|}
\hline & \multicolumn{5}{|c|}{ Nilai } & \multirow[t]{2}{*}{ Jumlah } & \multirow{2}{*}{ Persentase } \\
\hline & $\mathbf{A}$ & B & $\mathrm{C}$ & D & $\mathbf{E}$ & & \\
\hline P1 & $13 \times 5$ & $6 \times 4$ & $1 \times 3$ & & & 92 & $92 \%$ \\
\hline $\mathrm{P} 2$ & $15 \times 5$ & $4 \times 4$ & $1 \times 3$ & & & 94 & $94 \%$ \\
\hline P3 & $13 \times 5$ & $7 \times 4$ & & & & 93 & $93 \%$ \\
\hline P4 & $7 \times 5$ & $12 \times 4$ & $1 \times 3$ & & & 86 & $86 \%$ \\
\hline P5 & $5 \times 5$ & $11 \times 4$ & $4 \times 3$ & & & 81 & $81 \%$ \\
\hline P6 & $14 \times 5$ & $3 \times 4$ & $3 \times 3$ & & & 91 & $91 \%$ \\
\hline P7 & $13 \times 5$ & $4 \times 4$ & $3 \times 3$ & & & 90 & $90 \%$ \\
\hline P8 & $10 \times 5$ & $8 \times 4$ & $2 \times 3$ & & & 88 & $88 \%$ \\
\hline P9 & $16 \times 5$ & $4 \times 4$ & & & & 96 & $96 \%$ \\
\hline $\mathrm{P} 10$ & & & $8 \times 3$ & $9 \times 2$ & $3 \times 1$ & 45 & $45 \%$ \\
\hline \multicolumn{7}{|c|}{ Rata-Rata } & $85.6 \%$ \\
\hline
\end{tabular}

Rata-rata indeks pengujian terhadap User Acceptance testing yaitu $85.6 \%$, sehingga dapat disimpulkan bahwa sistem layanan publik menggunakan metode location base service berfungsi dengan baik serta dapat membantu kinerja terkait performance, social influence, effort expectancy, supporting facilitating, use behavior dan behavioral intention.

\section{KESIMPULAN}

Kesimpulan dalam penelitian ini yaitu :

a. Penelitian yang dilakukan ini telah menghasilkan rancangan dan aplikasi tentang Pelayanan Kependudukan di Kantor Camat Air Gegas Berbasis Android.

b. Dengan adanya aplikasi pelayanan kependudukan ini, masyarakat dapat mempermudah dan mempersingkat dalam proses pelayanan pembuatan surat.

c. Location base service memperyakin lokasi user dan mencegah pengajuan surat palsu.

d. Implementasi dilakukan dengan cara menerapkannya secara bertahap kemudian, dilakukan pengembangan dan pengujian kembali dengan tujuan mengetahui masih ada atau tidak kesalahan terhadap program.

\section{DAFTAR PUSTAKA}

[1] E. Prasetyo, "Sistem Informasi Dokumentasi dan Kearsipan Berbasis Client-Server pada Bank Sumsel Babel Cabang Sekayu," J. Tek. Inform. Politek. Sekayu, 2017.

[2] R. Yayat, "Kualitas Pelayanan Publik Bidang Administrasi Kependudukan Di Kecamatan Gamping," J. Ilm. Magister Ilmu Adm., 2017.

[3] A. Fredriksson, "Location-allocation of public services - Citizen access, transparency and 
measurement. A method and evidence from Brazil and Sweden," Socioecon. Plann. Sci., 2017.

[4] S. S. Syam and M. J. Côté, "A comprehensive location-allocation method for specialized healthcare services," Oper. Res. Heal. Care, vol. 1, no. 4, pp. 73-83, 2012.

[5] J. Alfa and A. Jananto, "Sistem Informasi Publik Layanan Kesehatan menggunakan Metode Location Based Service di Kota Semarang," J. Teknol. Inf. Din., 2014.

[6] M. Mas'ud, "Pemanfaatan Teknologi Sistem Informasi untuk Meningkatkan Penjualan Hasil Produk UMKM Logam di Kota Pasuruan," Engagement, 2017.

[7] Y. Yang, "Is transparency a double-edged sword in citizen satisfaction with public service? Evidence from China's public healthcare," J. Serv. Theory Pract., vol. 28, no. 4, pp. 484-506, 2018.

[8] T. Mantoro, Laurentinus, N. Agani, and M. A. Ayu, "Improving the security guarantees, authenticity and confidentiality in short message service of mobile applications," in Proceedings of 2016 4th International Conference on Cyber and IT Service Management, CITSM 2016, 2016.

[9] D. Anggraeni and S. Iriani, "Sistem Informasi Pengarsipan Surat Masuk Dan Surat Keluar Pada Kantor Kecamatan Pringkuku," Indones. J. Netw. Secur., 2013.

[10] M. Rifauddin, "Pengelolaan Arsip Elektronik Berbasis Teknologi," Khizanah Al- Hikmah J. Ilmu Perpustakaan, Informasi, dan Kearsipan, 2016.

[11] H. A. B. Hakim, "OMEKA: Aplikasi Pengelola Arsip Digital dalam Berbagai Format," Khazanah J. Pengemb. Kearsipan, 2016.

[12] F. Latif and aditya wirangga Pratama, "Perancangan Sistem Informasi Manajemen Arsip Elektronik (E-Arsip) Berbasis Microsoft Access Pada PT HI-TEST," J. Akuntansi,Ekonomi dan Manaj. Bisnis, 2015.

[13] A. Rachmawati, A. Nugraha, and M. Awaluddin, "Desain Aplikasi Mobile Informasi Pemetaan Jalur Batik Solo Trans Berbasis Android Menggunakan Location Based Service,” J. Geod. Undip, 2017.

[14] S. Xianhua, D. Zhenjun, and C. Rong, "Research on mobile location service design based on Android," in Proceedings - 5th International Conference on Wireless Communications, Networking and Mobile Computing, WiCOM 2009, 2009.

[15] E. Retnoningsih, "Aplikasi Informasi Telepon Darurat Menggunakan Android Berbasis Location Based Service (Lbs)," J. Semin. Nas. Sains dan Teknol., 2016.

[16] H. P. Utama, O. D. Nurhayati, and I. P. Windasari, "Pembuatan Aplikasi Memantau Lokasi Anak Berbasis Android Menggunakan Location Based Service,” J. Teknol. dan Sist. Komput., 2016. 